\title{
ANALISIS PENGARUH KINERJA KEUANGAN TERHADAP TINGKAT BAGI HASIL DEPOSITO MUDHARABAH PADA BANK UMUM SYARIAH DI INDONESIA TAHUN 2012-2018
}

\author{
Nia Sulfiyani ${ }^{1}$, Rimi Gusliana Mais ${ }^{2}$ \\ PT. Transindo Buanamas Sentosa ${ }^{1}$ \\ Komplek Ruakn Gading Bukit Indah B. J/12, Jakarta \\ Program Studi Akuntansi ${ }^{2}$ \\ Sekolah Tinggi Ilmu Ekonomi Indonesia Jakarta Indonesia \\ niasulfiyani90@gmail.com ${ }^{1}$, rimigusliana@gmail.com ${ }^{2}$
}

\begin{abstract}
Abtrak - Penelitian ini bertujuan untuk mengetahui pengaruh Retun On Asset (ROA), Financing to Deposit Ratio (FDR), Capital Adequacy Ratio (CAR), Biaya Operasional terhadap Pendapatan Operasional (BOPO), dan Non Performing Financing (NPF) terhadap Tingkat Bagi Hasil Deposito Mudharabah pada Bank Umum Syariah di Indonesia Tahun 2012-2018. Hasil analisis menunjukkan bahwa Capital Adequacy Ratio (CAR) berpengaruh negatif dan signifikan terhadap Tingkat Bagi Hasil Deposito Mudharabah yang berarti sebesar apapun nilai CAR perusahaan Bank Umum Syariah (BUS) maka mengakibatkan semakin rendah pula Tingkat Bagi Hasil Deposito Mudharabah. Retun On Asset (ROA), Financing to Deposit Ratio (FDR), Biaya Operasional terhadap Pendapatan Operasional (BOPO), dan Non Performing Financing (NPF) tidak berpengaruh terhadap Tingkat Bagi Hasil Deposito Mudharabah, yang berarti sebesar apapun ROA, FDR, BOPO, dan NPF tidak akan mempengaruhi investasi keuntungan, penyaluran jumlah kredit, biaya operasional dan pendapatan, pembiayaan bermasalah terhadap tingkat bagi hasil deposito mudharabah.
\end{abstract}

Kata Kunci : ROA, FDR, CAR, BOPO, NPF, Tingkat Bagi Hasil, Deposito Mudharabah.

\section{PENDAHULUAN}

\subsection{Latar Belakang Masalah}

Kinerja keuangan yang digunakan adalah berbagai macam Rasio Keuangan diantaranya, Rasio Profitabilitas yang terdiri dari ROA (Return on Assets). Penelitian Andryani Isna K dan Kunti Sunaryo (2012) mengenai ROA menunjukkan hasil ROA berpengaruh negatif terhadap tingkat bagi hasil deposito mudharabah, sedangkan penelitian Reandy Sabtatianto, Muhammad Yusuf (2018) menunjukkan hasil ROA berpengaruh positif terhadap tingkat bagi hasil deposito mudharabah, dan penelitian Haedar Ali (2018) menunjukkan bahwa ROA tidak berpengaruh terhadap tingkat bagi 
hasil deposito mudharabah.

Rasio Likuiditas terdiri dari FDR (Financing Deposit Ratio). Penelitian Achmad Agus Yasin Fadli (2018) mengenai FDR (Financing to Deposits Ratio) menunjukkan hasil FDR berpengaruh negatif terhadap tingkat bagi hasil deposito mudharabah, sedangkan penelitian Laila Mugi Harfiah, Atiek Sri Purwati \& Permata Ulfah (2016:19) menunjukkan hasil FDR berpengaruh positif terhadap tingkat bagi hasil deposito mudharabah, dan penelitian Rachmawaty dan Tiffany Andari Yudiana (2015) menunjukkan bahwa FDR tidak berpengaruh terhadap tingkat bagi hasil deposito mudharabah.

Rasio Solvabilitas dengan CAR (Capital Adequacy Ratio). Penelitian Umiyati dan Shella Muthya Syarif (2016) mengenai Capital Adequacy Ratio (CAR) menunjukkan hasil CAR berpengaruh negatif terhadap tingkat bagi hasil deposito mudharabah, sedangkan penelitian Gundari (2015) menunjukkan hasil CAR berpengaruh positif terhadap tingkat bagi hasil deposito mudharabah, dan penelitian Siti Rahayu (2015) menunjukkan bahwa CAR tidak berpengaruh terhadap tingkat bagi hasil deposito mudharabah.

Rasio Efisiensi terdiri dari BOPO (Biaya Operasional terhadap Pendapatan Operasional). Penelitian Ridhatullah Indrajati, Septyana Prasetyaningrum (2014) mengenai Biaya Operasional terhadap Pendapatan Operasional (BOPO) menunjukkan hasil BOPO berpengaruh negatif terhadap tingkat bagi hasil deposito mudharabah, sedangkan penelitian Wulandari Nur Cahyani, Syaikhul Falah, Ratna Yulia Wijayanti (2017) menunjukkan hasil BOPO berpengaruh positif terhadap tingkat bagi hasil deposito mudharabah, dan penelitian Agus Farianto (2014) menunjukkan bahwa BOPO tidak berpengaruh terhadap tingkat bagi hasil deposito mudharabah.

Rasio Kualitas Aktiva Produktif (Non Performing Financing). Penelitian Achmad Agus Yasin Fadli (2018) menunjukkan hasil NPF berpengaruh positif terhadap tingkat bagi hasil deposito mudharabah, sedangkan penelitian Nana Nofianti, Tenny Badina dan Aditiya Erlangga (2015) menunjukkan bahwa NPF tidak berpengaruh terhadap tingkat bagi hasil deposito mudharabah.

Berdasarkan latar belakang di atas, maka penulis ingin melakukan penelitian lebih lanjut dalam bentuk tesis dengan judul "ANALISIS PENGARUH KINERJA KEUANGAN TERHADAP TINGKAT BAGI HASIL DEPOSITO MUDHARABAH 


\section{PADA BANK UMUM SYARIAH DI INDONESIA TAHUN 2012-2018”.}

\subsection{Perumusan Masalah}

Berdasarkan pada latar belakang di atas maka dapat dirumuskan sebagai berikut:

1. Apakah Return On Asset (ROA) berpengaruh terhadap tingkat bagi hasil deposito mudharabah pada Bank Umum Syariah di Indonesia tahun 2012-2018 ?

2. Apakah Financing to Deposit Ratio (FDR) berpengaruh terhadap tingkat bagi hasil deposito mudharabah pada Bank Umum Syariah di Indonesia tahun 2012-2018?

3. Apakah Capital Adequacy Ratio (CAR) berpengaruh terhadap tingkat bagi hasil deposito mudharabah pada Bank Umum Syariah di Indonesia tahun 2012-2018 ?

4. Apakah Biaya Operasional terhadap Pendapatan Operasional (BOPO) berpengaruh terhadap tingkat bagi hasil deposito mudharabah pada Bank Umum Syariah di Indonesia tahun 2012-2018?

5. Apakah Non Performing Financing (NPF) berpengaruh terhadap tingkat bagi hasil deposito mudharabah pada Bank Umum Syariah di Indonesia tahun 2012-2018?

\section{KAJIAN PUSTAKA}

\subsection{Tingkat Bagi Hasil Deposito Mudharabah}

Tingkat bagi hasil adalah keuntungan atau hasil yang diperoleh dari pengelolaan dana baik investasi maupun transaksi jual beli yang diberikan nasabah (Umiyati dan Syarif 2016). Bagi hasil dalam bank syariah menggunakan istilah nisbah bagi hasil, yaitu proposi bagi hasil antara nasabah dan bank umum syariah (Isna dan Sunaryo, 2012).

\subsection{Kinerja Keuangan}

Menurut Kasmir (2012:197) menjelaskan bahwa kegagalan atau keberhasilan dapat dijadikan sebagai bahan acuan untuk perencanaan laba ke depan, sekaligus kemungkinan untuk menggantikan manajemen yang baru terutama setelah manajemen lama mengalami kegagalan.

\section{Return on Asset}

Menurut Sujarweni (2017:56) ROA merupakan rasio yang digunakan untuk mengukur kemampuan dari modal yang diinvestasikan dalam keseluruhan aktiva untuk mengasilkan keuntungan netto.

$$
\text { ROA }=\frac{\text { Laba Sebelum Pajak }}{\text { Rata }- \text { Rata Total Aset }} \times 100 \%
$$




\section{Financing to Deposit Ratio (FDR)}

Menurut Ikatan Bankir Indonesia (2016:287) FDR merupakan perbandingan antara jumlah pembiayaan yang diberikan dengan sumber dana yang berasal dari dana masyarakat (giro, tabungan, dan simpanan berjangka).

$$
\text { FDR }=\frac{\text { Jumlah Pembiayaan }}{\text { Total Dana Pihak Ketiga }} \times 100 \%
$$

\section{Capital Adequacy Ratio (CAR)}

Menurut Kasmir (2014:46), CAR adalah perbandingan rasio tersebut antara rasio modal terhadap Aktiva Tertimbang Menurut Resiko (ATMR) dan sesuai dengan ketentuan pemerintah.

$$
\mathrm{CAR}=\frac{\text { Modal Bank }}{\text { Aktiva Tertimbang Menurut Risiko }} \times 100 \%
$$

\subsection{Biaya Operasional dan Pendapatan Operasional (BOPO)}

Menurut Ikatan Bankir Indonesia (2016:287) BOPO adalah perbandingan antara total beban operasional terhadap pendapatan operasinal.

$$
\text { BOPO }=\frac{\text { Biaya Operasional }}{\text { Pendapatan Operasional }} \times 100 \%
$$

\section{Non Performing Financing (NPF)}

Menurut Siswanti (2013:82), Non Performing Financing (NPF) merupakan rasio perbandingan pembiayaan yang bermasalah dengan total penyaluran dana yang disalurkan kepada masyarakat.

$$
\mathrm{NPF}=\frac{\text { Jumlah Pembiayaan Bermasalah }}{\text { Total Pembiayaan }} \mathbf{x} 100 \%
$$

\subsection{Kerangka Konseptual Penelitian}

Berdasarkan penelitian terdahulu (dari pengembangan hipotesis pengembangan), dapat disimpulkan bahwa hipotesis yang diambil penulis, sebagi berikut:

$\mathrm{H}_{1}=\mathrm{ROA}$ berpengaruh terhadap Tingkat Bagi Hasil Deposito Mudharabah pada Bank

Umum Syariah di Indonesia tahun 2012-2018.

$\mathrm{H}_{2}=$ FDR berpengaruh terhadap Tingkat Bagi Hasil Deposito Mudharabah pada Bank

Umum Syariah di Indonesia tahun 2012-2018.

$\mathrm{H}_{3}=\mathrm{CAR}$ berpengaruh terhadap Tingkat Bagi Hasil Deposito Mudharabah pada Bank

Umum Syariah di Indonesia tahun 2012-2018.

$\mathrm{H}_{4}=$ BOPO berpengaruh terhadap Tingkat Bagi Hasil Deposito Mudharabah pada Bank

Umum Syariah di Indonesia tahun 2012-2018. 
$\mathrm{H}_{5}=\mathrm{NPF}$ berpengaruh terhadap Tingkat Bagi Hasil Deposito Mudharabah pada Bank Umum Syariah di Indonesia tahun 2012-2018.

\section{METODA PENELITIAN}

\section{Operasional Variabel}

Variabel dependen adalah variabel yang dipengaruhi atau dijelaskan oleh variabel bebas. variabel yang nilainya dipengaruhi oleh variabel independen. Didalam penelitian ini variabel yang digunakan adalah Tingkat Bagi Hasil Deposito Mudharabah.

Variabel independen atau variabel bebas adalah variabel yang akan membantu menjelaskan dan variabel yang berpengaruh terhadap variabel dependen. Variabel independen dalam penelitan ini adalah Return on Asset (ROA), Financing to Deposit Ratio (FDR), Capital Adequacy Ratio (CAR), Biaya Operasional terhadap Pendapatan Operasional (BOPO), dan Non Performing Financing (NPF).

\section{Hasil Penelitian}

\section{Analisis Statistik Deskriptif}

\begin{tabular}{lcccccc}
\multicolumn{8}{c}{ Hasil Uji Deskriptif } \\
\hline & $\boldsymbol{R O A}$ & $\boldsymbol{F D R}$ & $\boldsymbol{C A R}$ & BOPO & NPF & $\begin{array}{c}\text { Tingkat } \\
\text { Bagi Hasil }\end{array}$ \\
\hline Mean & 0.682857 & 102.1643 & 24.31000 & 91.01429 & 2.328571 & 0.053143 \\
Maximum & 5.070000 & 299.9000 & 159.8000 & 168.7700 & 2.340000 & 0.090000 \\
Minimum & -12.44000 & 74.59000 & 11.69000 & 60.18000 & 0.000000 & 0.020000 \\
Std. Dev. & 2.364889 & 37.55216 & 20.98052 & 19.62287 & 1.418792 & 0.011363 \\
Observations & 70 & 70 & 70 & 70 & 70 & 70 \\
\hline Sumber: Data diolah dengan Eviews 10.0 & & & &
\end{tabular}

Berdasarkan hasil uji deskriptif, maka dapat diinterpretasikan sebagai berikut :

\section{Tingkat Bagi Hasil Deposito Mudharabah}

Tingkat Bagi Hasil Deposito Mudharabah menggunakan hasil angka berdasarkan profit distribution pada Bank Umum Syariah. Berdasarkan hasil analisis deskriptif dari data selama periode penelitian dapat dilihat bahwa nilai tertinggi (maximum) Tingkat Bagi Hasil Deposito Mudharabah adalah 0.09\% yang merupakan nilai Tingkat Bagi Hasil Deposito Mudharabah pada PT. Bank BRI Syariah (BRIS) tahun 2014. Nilai terendah (minimum) Tingkat Bagi Hasil Deposito Mudharabah adalah 0.02\% yang merupakan nilai Tingkat Bagi Hasil Deposito Mudharabah pada PT. Bank Maybank Syariah Indonesia (MSI) tahun 2018. Nilai rata-rata (mean) sebesar $0.05 \%$ dengan simpangan baku (Standar Deviasi) sebesar 0.011363. 


\section{Return On Asset (ROA)}

Return On Asset (ROA) memiliki nilai tertinggi (maximum) ROA adalah 5.07\% yang merupakan nilai ROA pada PT. Bank Maybank Syariah Indonesia (MSI) tahun 2017. Nilai terendah (minimum) ROA adalah $-12.44 \%$ yang merupakan nilai ROA pada PT. Bank Maybank Syariah Indonesia (MSI) tahun 2015. Simpangan baku (Standar Deviasi) sebesar 2.36. Selain itu, diketahui nilai rata-rata (mean) Bank Umum Syariah memiliki ROA sebesar $0.68 \%$ dimana menurut peringkat penilaian rasio ROA, rata-rata ROA pada Bank Umum Syariah sudah termasuk kedalam penilaian yang cukup sehat dikarenakan nilai ROA $0.68 \%$ merupakan kriteria ROA yang cukup sehat $0.5 \%<$ ROA $\leq 1.25 \%$.

\section{Financing to Deposit Ratio (FDR)}

Financing to Deposit Ratio (FDR) memilik nilai tertinggi (maximum) FDR adalah 299.90\% yang merupakan nilai FDR pada PT. Bank Maybank Syariah Indonesia (MSI) tahun 2018. Nilai terendah (minimum) FDR adalah 74.59\% yang merupakan nilai FDR pada PT. Bank BRI Syariah (BRIS) tahun 2018. Simpangan baku (Standar Deviasi) sebesar 37.55. Selain itu, diketahui nilai rata-rata (mean) Bank Umum Syariah memiliki FDR sebesar $102.16 \%$ dimana menurut peringkat penilaian rasio FDR, rata-rata FDR pada Bank Umum Syariah sudah termasuk kedalam penilaian yang kurang sehat dikarenakan nilai FDR 102.16\% merupakam kriteria FDR yang kurang sehat $100 \%<\mathrm{FDR} \leq 120 \%$

\section{Capital Adequacy Ratio (CAR)}

Capital Adequacy Ratio (CAR) memiliki nilai tertinggi (maximum) CAR adalah $159.80 \%$ yang merupakan nilai CAR pada PT. Bank Maybank Syariah Indonesia (MSI) tahun 2018. Nilai terendah (minimum) CAR adalah $11.69 \%$ yang merupakan nilai CAR pada PT. Bank Syariah Bukopin (BSB) tahun 2013. Simpangan baku (Standar Deviasi) sebesar 20.98. Selain itu, diketahui nilai rata-rata (mean) Bank Umum Syariah memiliki CAR sebesar $24.31 \%$ dimana menurut peringkat penilaian rasio CAR, rata-rata CAR pada Bank Umum Syariah sudah termasuk kedalam penilaian yang sangat sehat dikarenakan nilai CAR $24.31 \%$ merupakam kriteria CAR yang sangat sehat CAR $\geq 12 \%$.

5. Biaya Operasional terhadap Pendapatan Operasional (BOPO)

Biaya Operasional terhadap Pendapatan Operasional (BOPO) memiliki nilai tertinggi (maximum) BOPO adalah $168.77 \%$ yang merupakan nilai BOPO pada PT. 
Bank Maybank Syariah Indonesia (MSI) tahun 2015. Nilai terendah (minimum) BOPO adalah 60.18\% yang merupakan nilai BOPO pada PT. Bank Panin Dubai Syariah (BPDS) tahun 2012. Simpangan baku (Standar Deviasi) sebesar 19.62287. Selain itu, diketahui nilai rata-rata (mean) Bank Umum Syariah memiliki BOPO sebesar 91.01\% dimana menurut peringkat penilaian rasio BOPO, rata-rata BOPO pada Bank Umum Syariah sudah termasuk kedalam penilaian yang tidak sehat dikarenakan nilai BOPO 91.01\% merupakam kriteria BOPO yang tidak sehat BOPO $>89 \%$.

\section{Non Performing Financing (NPF)}

Non Performing Financing (NPF) memiliki nilai tertinggi (maximum) NPF adalah 2.34\% yang merupakan nilai NPF pada PT. Bank BRI Syariah (BRIS) tahun 2013. Nilai terendah (minimum) NPF adalah $0.00 \%$ yang merupakan nilai NPF pada PT. Bank Maybank Syariah Indonesia (MSI) tahun 2018. Simpangan baku (Standar Deviasi) sebesar 1.41. Selain itu, diketahui nilai rata-rata (mean) Bank Umum Syariah memiliki NPF sebesar $2.33 \%$ dimana menurut peringkat penilaian rasio CAR, rata-rata CAR pada Bank Umum Syariah sudah termasuk kedalam penilaian yang sangat sehat dikarenakan nilai NPF $2.33 \%$ merupakam kriteria NPF yang sehat $2 \%<\mathrm{NPF} \leq 5 \%$.

\section{Hasil Uji Asumsi Klasik}

\section{Hasil Uji Normal}

\section{Hasil Uji Normalitas}

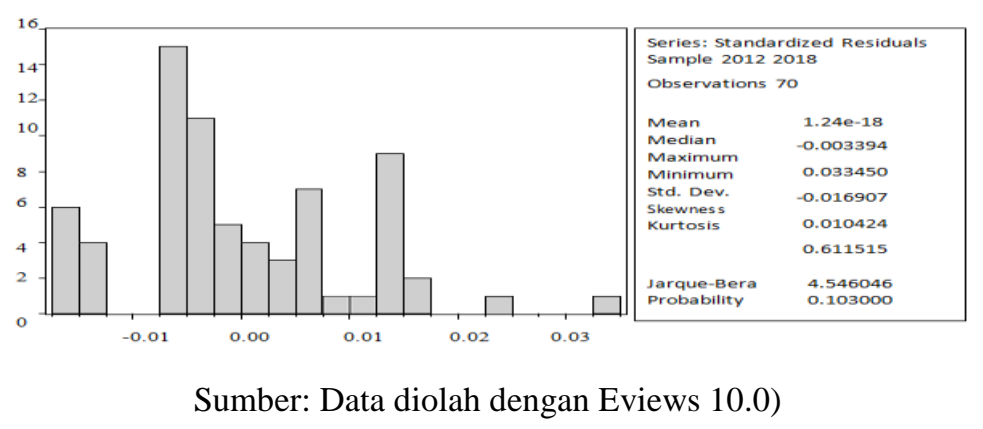

Dari hasil yang didapatkan bhwa nilai probabilitas sebesar 0.103000, dengan demikian bahwa data normal karena Probabilitas Jarque-Bera $>0.05$. 


\section{Hasil Uji Multikolinearitas}

\section{Hasil Uji Multikolinearitas}

\begin{tabular}{|c|c|c|c|}
\hline \multicolumn{4}{|c|}{ 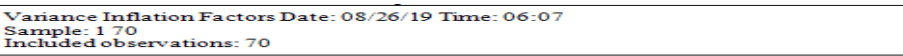 } \\
\hline Variable & $\begin{array}{l}\text { Coefficient } \\
\text { Variance }\end{array}$ & $\begin{array}{l}\text { Uncentered } \\
\text { VIF }\end{array}$ & Centered VIF \\
\hline $\begin{array}{ll}\mathrm{X1} & \text { ROA } \\
\mathrm{X} 2 & \mathrm{FDR} \\
\mathrm{X3} & \mathrm{CAR} \\
\mathrm{X} 4 & \mathrm{BOPO} \\
\mathrm{X} 5 & \text { NPF } \\
\mathrm{C} & \end{array}$ & 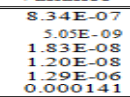 & $\begin{array}{l}2.977774 \\
35.71715 \\
11.14811 \\
6214277 \\
58998725 \\
8397471\end{array}$ & $\begin{array}{l}2.745546 \\
4.197614 \\
4.736608 \\
2.722641 \\
1.526707 \\
\text { N. }\end{array}$ \\
\hline
\end{tabular}

Hasil pengujian multikolinearitas dapat dilihat pada tabel 4.12, nilai Centered VIF ROA 2.745546, nilai Centered VIF FDR 4.197614, nilai Centered VIF CAR 4.736608, nilai Centered VIF BOPO 2.722641 dan nilai Centered VIF NPF1.526707. Berdasarkan tampilan tersebut dapat diketahui bahwa koefisien korelasi masing-masing variabel bebas Centered VIF <10 sehingga tidak terdapat masalah multikolinearitas.

\section{Hasil Uji Heteroskedastisitas}

\section{Hasil Uji Heteroskedastisitas}

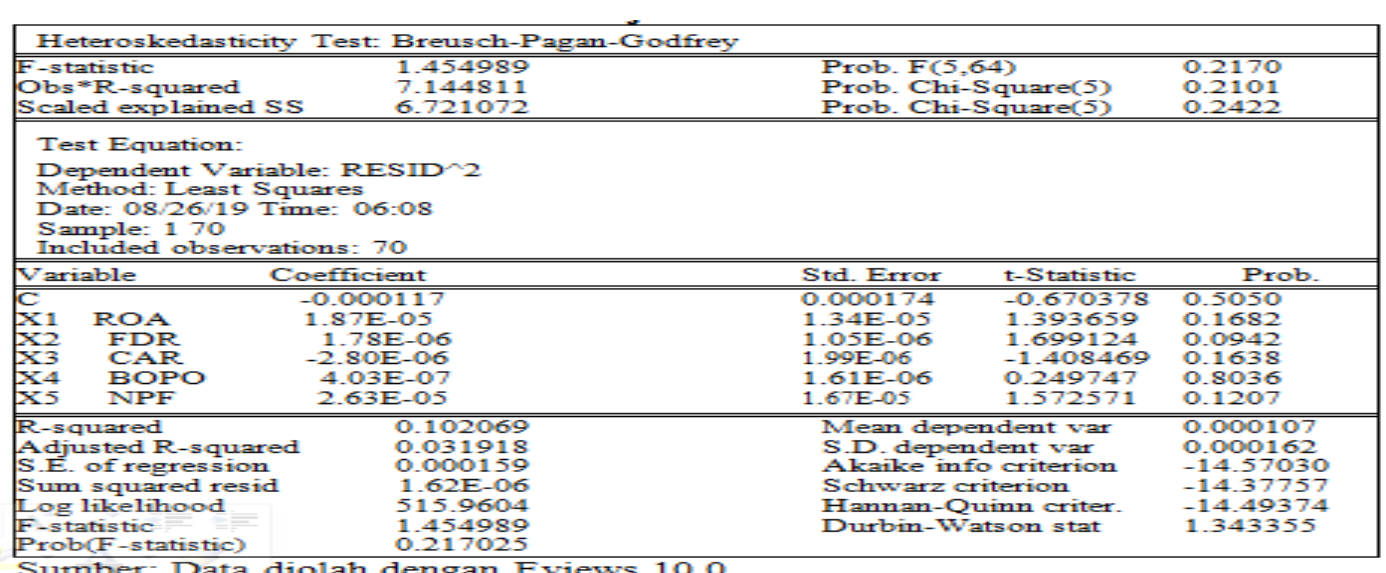

Pada tabel di atas, nilai probabilitas $o b s^{*} R$-Square sebesar 0.210. Hasil ini menunjukkan bahwa nilai probabilitas $o b s * R$-Square lebih besar dari 0.05, maka dengan demikian tidak terjadi heteroskedastisitas pada data.

\section{Hasil Uji Autokorelasi}

\section{Hasil Uji Autokorelasi}

\begin{tabular}{|c|c|c|c|c|}
\hline \multicolumn{5}{|c|}{$\begin{array}{l}\text { Dependent Variable: Y TINGKAT_BAGI_HASIL_DEPOSITO Method: Least Squares } \\
\text { Date: } 08 / 26 / 19 \text { Time: } 06: 16 \mathrm{Sample}: 170 \\
\text { Included observations: } 70\end{array}$} \\
\hline Variable & Coefficient & Std. Error & t-Statistic & Prob. \\
\hline X1 ROA & 0.000781 & 0.000913 & 0.854941 & 0.3958 \\
\hline $\mathrm{X} 2 \mathrm{FDR}$ & $2.42 \mathrm{E}-05$ & $7.11 \mathrm{E}-05$ & 0.340755 & 0.7344 \\
\hline X3 CAR & -0.000238 & 0.000135 & -1.761104 & 0.0830 \\
\hline $\mathrm{X} 4 \quad \mathrm{BOPO}$ & $9.77 \mathrm{E}-05$ & 0.000110 & 0.891253 & 0.3761 \\
\hline X5 5 NPF & 0.000587 & 0.001135 & 0.516911 & 0.6070 \\
\hline c & 0.045668 & 0.011855 & 3.852092 & 0.0003 \\
\hline R-squared & 0.158316 & Mean dey & ndent var & 0.053143 \\
\hline Adjusted R-squared & 0.092559 & S.D. dep & dent var & 0.011363 \\
\hline S.E. of regression & 0.010824 & Akaike ix & criterion & -6.132281 \\
\hline Sum squared resid & 0.007498 & Schwarz & iterion & -5.939553 \\
\hline Loglikelihood & 220.6298 & Hannan- & inn criter. & -6.055727 \\
\hline F-statistic & 2.407604 & Durbin- & tsonstat & 1.916261 \\
\hline Prob(F-statistic) & 0.046050 & & & \\
\hline
\end{tabular}


Menentukan ada tidaknya autokorelasi dapat dilihat berapa nilai $d$ pada tabel uji DW seperti pada tabel ini

\begin{tabular}{|c|c|c|c|}
\hline $\mathrm{dU}$ & DW & $4-\mathrm{dU}$ & Kesimpulan \\
\hline 1,7683 & 1.916261 & 2,2317 & Tidak Ada Autokorelasi \\
\hline
\end{tabular}

Tabel Tabel Autokorelasi Uji Durbin Watson

Hasil uji DW terhadap model regresi menghasilkan koefisien Durbin Watson (DW Stat) sebesar 1.916261. Hasil uji statistic Durbin Watson berada pada daerah $d U \leq d W \leq 4-$ $d U$ atau $1,7683 \leq 1.916261 \leq 2,2317$, sehingga dapat disimpulkan data pada model regresi Tidak terdapat autokorelasi positif dan negatif antara variabel sehingga model regresi layak digunakan.

\section{Uji Pemilihan Model Estimasi Data Panel}

\section{Uji Tahap Analisis Data Panel}

Hasil Uji Chow Test (Common Effect Models vs Fixed Effect Models)

Hasil Uji Chow Test

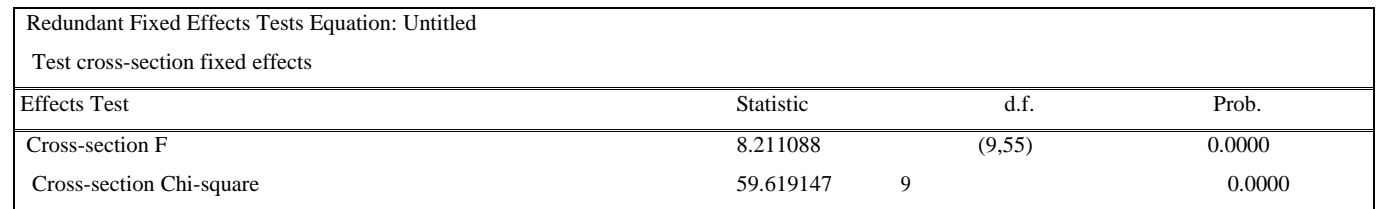

Sumber: Data diolah dengan Eviews 10.0

Dari tabel di atas dapat diketahui bahwa probabilitas chi-square adalah 0,0000 atau lebih kecil dari $\alpha=5 \%$ maka model yang tepat adalah fixed effectmodel.

\section{Hasil Uji Hausman Test (Fixed Effect Models vs Random Effect Models)}

Hasil Uji Hausman Test

\begin{tabular}{|lrrr|}
\hline $\begin{array}{l}\text { Correlated Random Effects - Hausman Test Equation: Untitled } \\
\text { Test cross-section random effects }\end{array}$ & & \\
\hline Test Summary & Chi-Sq. Statistic & Chi-Sq. d.f. & Prob. \\
\hline Cross-section random & 8.173053 & 5 & 0.1470 \\
\hline \hline
\end{tabular}

Sumber: Data diolah dengan Eviews 10.0

Pada tabel di atas probabilitas chi-square adalah 0.1470 atau probabilitas chi-square $>0.05$, maka model yang tepat adalah Random Effect Model. 
Hasil Uji Lagrange Multiplier (Common Effect Model vs Random Effect Model)

Hasil Uji Lagrange Multiplier (LM Test)

\begin{tabular}{|c|c|c|c|}
\hline \multicolumn{4}{|c|}{$\begin{array}{l}\text { Lagrange multiplier (LM) test for panel data Date: 08/26/19 Time: 06:08 } \\
\text { Sample: } 20122018 \\
\text { Total panel observations: } 70 \text { Probability in () }\end{array}$} \\
\hline Null (no rand. effect) Alternative & $\begin{array}{l}\text { Cross-section One- } \\
\text { sided }\end{array}$ & Period One-sided & Both \\
\hline \multirow[t]{2}{*}{ Breusch-Pagan } & 42.21852 & 0.783440 & 43.00196 \\
\hline & $(0.0000)$ & $(0.3761)$ & $(0.0000)$ \\
\hline \multirow[t]{2}{*}{ Honda } & 6.497578 & 0.885121 & 5.220357 \\
\hline & $(0.0000)$ & $(0.1880)$ & $(0.0000)$ \\
\hline \multirow[t]{2}{*}{ King-Wu } & 6.497578 & 0.885121 & 4.795041 \\
\hline & $(0.0000)$ & $(0.1880)$ & $(0.0000)$ \\
\hline \multirow[t]{2}{*}{ GHM } & -- & -- & 43.00196 \\
\hline & -- & -- & $(0.0000)$ \\
\hline
\end{tabular}

Sumber: Data diolah dengan Eviews 10.0

Dari hasil output di atas dapat dilihat bahwa nilai Prob. Breusch-Pagan (BP) sebesar 0.0000 (Pada kolom ketiga yaitu "Both"). sesuai hipotesis, jika Prob BP (0.0000 $<0,05)$ maka $\mathrm{H}_{0}$ ditolak dan $\mathrm{H}_{\mathrm{a}}$ diterima, dengan kata lain model yang cocok adalah Random effect Model.

\section{Kesimpulan Model}

Berdasarkan pengujian berpasangan terhadap ketiga model regresi data panel (Uji Chow Test, Uji Hausman Test, dan Uji Lagrange Multiplier), dapat disimpulkan sebagai berikut ini:

Kesimpulan Pengujian Model Regresi Data Panel

\begin{tabular}{|c|l|l|l|}
\hline No & \multicolumn{1}{|c|}{ Metode } & \multicolumn{1}{|c|}{ Pengujian } & Hasil \\
\hline 1 & Chow Test & Common Effect Model Vs Fixed Effect Model & Fixed Effect Model \\
\hline 2 & Hausman Test & Fixed Effect Model Vs Random Effect Model & Random Effect Model \\
\hline 3 & Lagrange Multiplier & Common Effect Model Vs Random Effect Model & Random Effect Model \\
\hline
\end{tabular}

Sumber : Data diolah (2019)

Hasil pengujian model regresi data panel atas ketiga model data panel, tujuannya untuk memperkuat kesimpulan pengujian berpasangan, yang merekomendasikan penggunaan random effect models yang akan dianalisis lebih lanjut dalam penelitian ini.

\section{Analisis Regresi Hasil Estimasi Random Effect Model}

\section{Hasil Uji Random Effect Models}

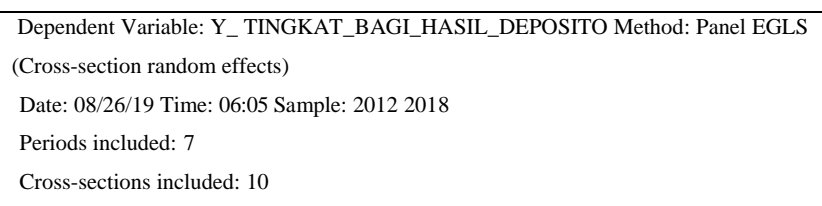




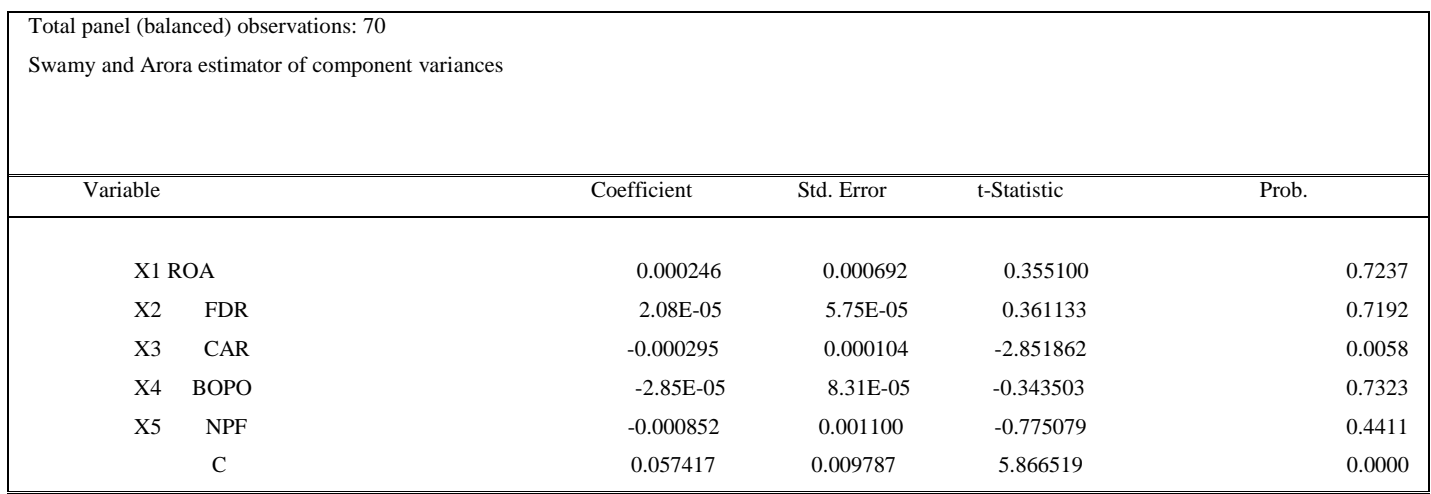

Sumber: Data diolah dengan Eviews 10.0

Berdasarkan hasil analisis regresi berganda di atas, maka dapat diperoleh suatu persamaan garis regresi sebagai berikut ini:

$$
\begin{aligned}
\mathrm{Y}_{\mathrm{it}}= & \alpha+\beta \mathrm{X} 1(\mathrm{ROA})_{\mathrm{it}}+\beta \mathrm{X} 2(\mathrm{FDR})_{\mathrm{it}}+\beta \mathrm{X} 3(\mathrm{CAR})_{\mathrm{it}}+\beta \mathrm{X} 4(\mathrm{BOPO})_{\mathrm{it}}+\beta \mathrm{X} 5(\mathrm{NPF})_{\mathrm{it}}+\varepsilon_{\mathrm{it}} \\
= & 0.057417+0.000246 \mathrm{ROA}_{\mathrm{it}}+0.00000208 \mathrm{FDR}_{\mathrm{it}}-0.000295 \mathrm{CAR}_{\mathrm{it}}- \\
& 0.0000285 \mathrm{BOPO}_{\mathrm{it}}-0.000852 \mathrm{NPF}_{\mathrm{it}}+\varepsilon_{\mathrm{it}}
\end{aligned}
$$

Berdasarkan hasil persamaan di atas, dapat disimpulkan:

a. Koefisien konstanta sebesar 0.057417, menyatakan bahwa menunjukkan bahwa jika ROA, FDR, CAR, BOPO, dan NPF dan konstanta, maka variabel Y 0.057417.

b. Dari hasil pengujian di atas, dapat diketahui bahwa nilai koefisien variabel Return On Asset (ROA) adalah sebesar 0.000246 menyatakan bahwa nilai tersebut menggambarkan setiap kenaikan Return On Asset (ROA) sebesar 1 persen maka akan menyebabkan kenaikan Tingkat Bagi Hasil Deposito Mudharabah sebesar 0.246 persen.

c. Dari hasil pengujian di atas, dapat diketahui bahwa nilai koefisien variabel Financing to Deposit Ratio (FDR) adalah sebesar 0.00000208 menyatakan bahwa nilai tersebut menggambarkan setiap kenaikan Financing to Deposit Ratio (FDR) sebesar 1 persen maka akan menyebabkan kenaikan Tingkat Bagi Hasil Deposito Mudharabah sebesar 0.00208 persen.

d. Dari hasil pengujian di atas, dapat diketahui bahwa nilai koefisien variabel Capital Adequacy Ratio (CAR) adalah sebesar -0.000295 menyatakan bahwa nilai tersebut menggambarkan setiap kenaikan Capital Adequacy Ratio (CAR) sebesar 1 persen maka akan menyebabkan penurunan Tingkat Bagi Hasil Deposito Mudharabah sebesar 0.295 persen. 
e. Dari hasil pengujian di atas, dapat diketahui bahwa nilai koefisien variabel Biaya Operasional terhadap Pendapatan Operasional (BOPO) adalah sebesar -0.0000285 menyatakan bahwa nilai tersebut menggambarkan setiap kenaikan Biaya Operasional terhadap Pendapatan Operasional (BOPO) sebesar 1 persen maka akan menyebabkan penurunan Tingkat Bagi Hasil Deposito Mudharabah sebesar 0.0285 persen.

f. Dari hasil pengujian di atas, dapat diketahui bahwa nilai koefisien variabel Non Performing Financing (NPF) adalah sebesar -0.000852 menyatakan bahwa nilai tersebut menggambarkan setiap kenaikan Non Performing Financing (NPF) sebesar 1 persen maka akan menyebabkan penurunan Tingkat Bagi Hasil Deposito Mudharabah sebesar 0.852 persen.

\section{Uji Koefisien Determinasi (Adjusted $\mathbf{R}^{2}$ )}

\section{Tabel Hasil Uji Koefisien Determinasi}

\begin{tabular}{|c|c|c|c|}
\hline \multicolumn{4}{|c|}{$\begin{array}{l}\text { Dependent Variable: Y_TINGKAT_BAGI_HASIL_DEPOSITO Method: Pane } \\
\text { (Cross-section random effects) } \\
\text { Date: 08/26/19 Time: 06:05 Sample: } 20122018 \\
\text { Periods included: } 7 \\
\text { Cross-sections included: } 10 \\
\text { Total panel (balanced) observations: } 70 \\
\text { Swamy and Arora estimator of component variances }\end{array}$} \\
\hline \multicolumn{4}{|c|}{ Weighted Statistics } \\
\hline R-squared & 0.177749 & Mean dependent var & 0.020464 \\
\hline Adjusted R-squared & 0.113511 & S.D. dependent var & 0.008299 \\
\hline S.E. of regression & 0.007814 & Sum squared resid & 0.003908 \\
\hline F-statistic & 2.767031 & Durbin-Watson stat & 1.230020 \\
\hline $\operatorname{Prob}(F-$-statistic) & 0.025210 & & \\
\hline
\end{tabular}

Sumber: Data diolah dengan Eviews 10.0

Hasil analisis koefisien determinasi yang disajikan pada tabel 4.23 menunjukkan bahwa Adjusted $\mathrm{R}^{2}=0.113511$, ini dapat ditafsirkan bahwa $11.35 \%$ bahwa Return On Asset (ROA), Financing to Deposit Ratio (FDR), Capital Adequacy Ratio (CAR), Biaya Operasional terhadap Pendapatan Operasional (BOPO), dan Non Performing Financing (NPF) mempengaruhi tingkat bagi hasil deposito mudharabah, sedangkan sisanya sebesar $88.65 \%$ dipengaruhi oleh variabel lain yang tidak digunakan pada penelitian ini.

\section{Uji T}




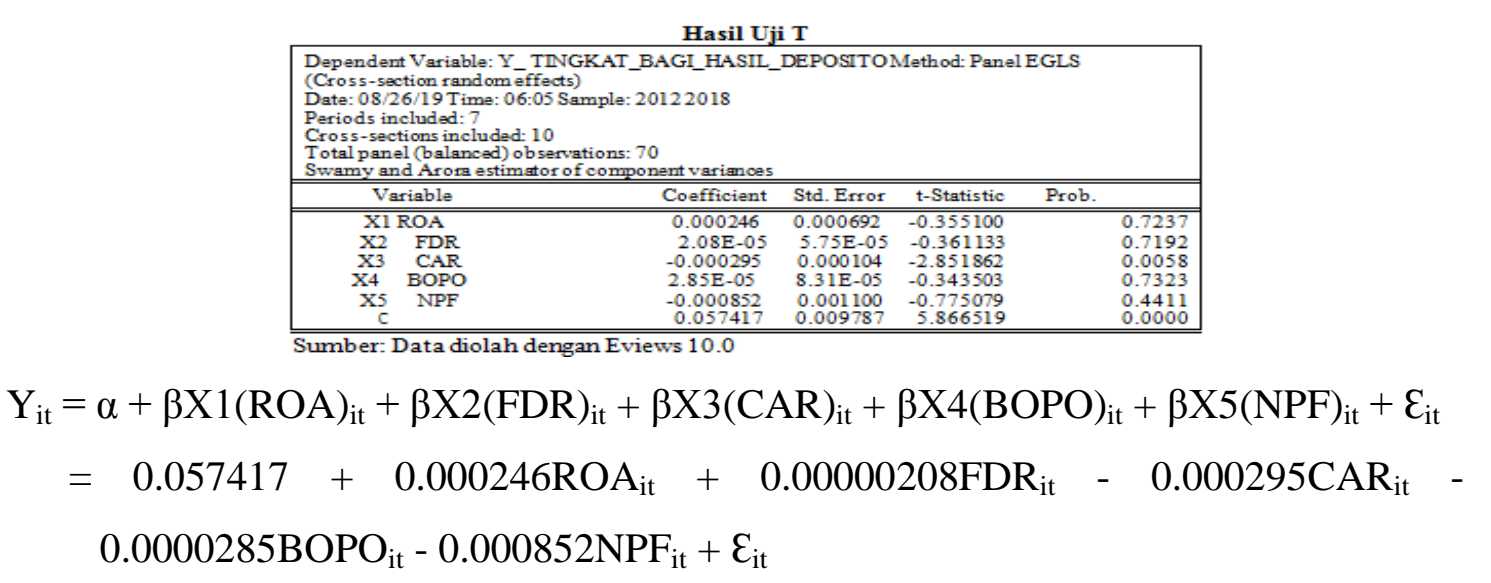

Berdasarkan tabel 4.25 di atas, maka hasil pengujian hipotesis dengan menggunakan uji T sebagai berikut ini:

1. Return On Asset (ROA) Tidak Berpengaruh terhadap Tingkat Bagi Hasil Deposito Mudharabah

Berdasarkan hasil uji parsial (uji t) dapat diartikan bahwa Return On Asset (ROA) tidak berpengaruh terhadap Tingkat Bagi Hasil Deposito Mudharabah pada Bank Umum Syariah, ditunjukkan dengan nilai signifikan 0.7237 lebih besar dari alpha $(\alpha=$ 0.05), nilai koefisien adalah sebesar 0.000246. Nilai signifikan Return On Asset (ROA) berada di atas 0.05 sehingga dapat disimpulkan bahwa Return On Asset (ROA) secara parsial tidak berpengaruh terhadap Tingkat Bagi Hasil Deposito Mudharabah, maka hal ini menunjukkan $\mathrm{H}_{\mathrm{o}}$ diterima atau $\mathrm{H}_{\mathrm{a}}$ ditolak, sehingga dapat disimpulkan bahwa hipotesis $\mathrm{H}_{\mathrm{a}}$ ditolak.

2. Financing to Deposit Ratio (FDR) Tidak Berpengaruh terhadap Tingkat Bagi Hasil Deposito Mudharabah

Berdasarkan hasil uji parsial (uji t) dapat diartikan bahwa Financing to Deposit Ratio (FDR) tidak berpengaruh terhadap Tingkat Bagi Hasil Deposito Mudharabah pada Bank Umum Syariah, ditunjukkan dengan nilai signifikan 0.7192 lebih besar dari alpha $(\alpha=0.05)$, nilai koefisien adalah sebesar 0.00000208. Nilai signifikan Financing to Deposit Ratio (FDR) berada di atas 0.05 sehingga dapat disimpulkan bahwa Financing to Deposit Ratio (FDR) secara parsial tidak berpengaruh terhadap Tingkat Bagi Hasil Deposito Mudharabah, maka hal ini menunjukkan $\mathrm{H}_{\mathrm{o}}$ diterima atau $\mathrm{H}_{\mathrm{a}}$ ditolak, sehingga dapat disimpulkan bahwa hipotesis $\mathrm{H}_{\mathrm{a}}$ ditolak.

3. Capital Adequacy Ratio (CAR) Berpengaruh Negatif Signifikan terhadap Tingkat Bagi Hasil Deposito Mudharabah 
Berdasarkan hasil uji parsial (uji t) dapat diartikan bahwa Capital Adequacy Ratio (CAR) berpengaruh negatif dan signifikan terhadap Tingkat Bagi Hasil Deposito Mudharabah pada Bank Umum Syariah, ditunjukkan dengan nilai signifikan 0.0058 lebih kecil dari alpha $(\alpha=0.05)$, nilai koefisien adalah sebesar -0.000295 . Nilai signifikan Capital Adequacy Ratio (CAR) berada di bawah 0.05 sehingga dapat disimpulkan bahwa Capital Adequacy Ratio (CAR) secara parsial berpengaruh negatif signifikan terhadap Tingkat Bagi Hasil Deposito Mudharabah, maka hal ini menunjukkan $\mathrm{H}_{\mathrm{o}}$ ditolak atau $\mathrm{H}_{\mathrm{a}}$ diterima, sehingga dapat disimpulkan bahwa hipotesis $\mathrm{H}_{\mathrm{a}}$ diterima.

4. Biaya Operasional terhadap Pendapatan Operasional (BOPO) Tidak Berpengaruh terhadap Tingkat Bagi Hasil Deposito Mudharabah

Berdasarkan hasil uji parsial (uji t) dapat diartikan bahwa Biaya Operasional terhadap Pendapatan Operasional (BOPO) tidak berpengaruh terhadap Tingkat Bagi Hasil Deposito Mudharabah pada Bank Umum Syariah, ditunjukkan dengan nilai signifikan 0.7323 lebih besar dari alpha $(\alpha=0.05)$, nilai koefisien adalah sebesar 0.0000285. Nilai signifikan Biaya Operasional terhadap Pendapatan Operasional (BOPO) berada di atas 0.05 sehingga dapat disimpulkan bahwa Biaya Operasional terhadap Pendapatan Operasional (BOPO) secara parsial tidak berpengaruh terhadap Tingkat Bagi Hasil Deposito Mudharabah, maka hal ini menunjukkan $\mathrm{H}_{\mathrm{o}}$ diterima atau $\mathrm{H}_{\mathrm{a}}$ ditolak, sehingga dapat disimpulkan bahwa hipotesis $\mathrm{H}_{\mathrm{a}}$ ditolak.

5. Non Performing Financing (NPF) Tidak Berpengaruh terhadap Tingkat Bagi Hasil Deposito Mudharabah

Berdasarkan hasil uji parsial (uji t) dapat diartikan bahwa Non Performing Financing (NPF) tidak berpengaruh terhadap Tingkat Bagi Hasil Deposito Mudharabah pada Bank Umum Syariah, ditunjukkan dengan nilai signifikan 0.4411 lebih besar dari alpha $(\alpha=0.05)$, nilai koefisien adalah sebesar -0.000852. Nilai signifikan Non Performing Financing (NPF) berada di atas 0.05 sehingga dapat disimpulkan bahwa Non Performing Financing (NPF) secara parsial tidak berpengaruh terhadap Tingkat Bagi Hasil Deposito Mudharabah, maka hal ini menunjukkan $\mathrm{H}_{\mathrm{o}}$ diterima atau $\mathrm{H}_{\mathrm{a}}$ ditolak, sehingga dapat disimpulkan bahwa hipotesis $\mathrm{H}_{\mathrm{a}}$ ditolak.

\section{Uji F}




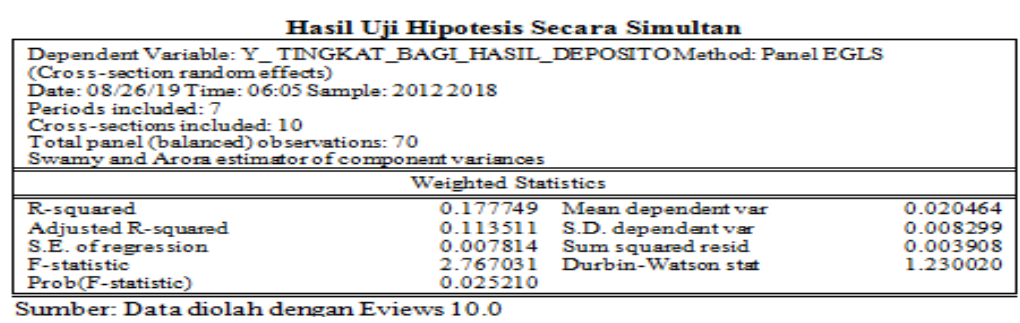

Dari hasil uji F yang telah dilakukan, variabel kinerja keuangan yaitu Return On Asset (ROA), Financing to Deposit Ratio (FDR), Capital Adequacy Ratio (CAR), Biaya Operasional terhadap Pendapatan Operasional (BOPO), dan Non Performing Financing (NPF) memiliki nilai Prob (F-statistic) adalah 0.025210, dengan taraf signifikan yaitu sebesar 0.05. Hal ini menunjukkan bahwa kinerja keuangan yaitu Return On Asset (ROA), Financing to Deposit Ratio (FDR), Capital Adequacy Ratio (CAR), Biaya Operasional terhadap Pendapatan Operasional (BOPO), dan Non Performing Financing (NPF) secara bersama-sama atau secara simultan berpengaruh signifikan terhadap Tingkat Bagi Hasil Deposito Mudharabah.

\section{KESIMPULAN DAN SARAN}

\subsection{Kesimpulan}

Adapun hasil analisis yang telah dilakukan dalam menganalisis perusahaan Bank Umum Syariah (BUS) di Indonesia tahun 2012-2018, maka dapat menarik kesimpulan dibawah ini:

1. Return On Asset (ROA) tidak berpengaruh terhadap Tingkat Bagi Hasil Deposito Mudharabah pada Bank Umum Syariah di Indonesia tahun 2012-2018.

2. Financing to Deposit Ratio (FDR) tidak berpengaruh terhadap Tingkat Bagi Hasil Deposito Mudharabah pada Bank Umum Syariah di Indonesia tahun 2012-2018.

3. Capital Adequacy Ratio (CAR) berpengaruh negatif dan signifikan terhadap Tingkat Bagi Hasil Deposito Mudharabah pada Bank Umum Syariah di Indonesia tahun 2012-2018.

4. Biaya Operasional terhadap Pendapatan Operasional (BOPO) tidak berpengaruh terhadap Tingkat Bagi Hasil Deposito Mudharabah pada Bank Umum Syariah di Indonesia tahun 2012-2018. 
5. Non Performing Financing (NPF) secara parsial tidak berpengaruh terhadap Tingkat Bagi Hasil Deposito Mudharabah pada Bank Umum Syariah di Indonesia tahun 2012-2018.

\subsection{Saran}

Berdasarkan hasil penelitian yang telah dikemukakan, maka dapat diberikan saran sebagai berikut ini:

1. Sebaiknya bank syariah dapat meningkatkan Return on Asset yang dicapai karena return atau laba yang diperoleh bank cukup besar bersumber dari pendapatan pengelolaan dana oleh bank sebagai mudharib.

2. Sebaiknya bank syariah berupaya mengoptimalkan tingkat bagi hasil deposito mudharabah yang diberikan kepada nasabah sehingga bank syariah dapat meningkatkan minat nasabah mendepositokan dananya di bank syariah

3. Penelitian selanjutnya mungkin dapat memperluas sampel penelitian dengan mempertimbangkan penggunaan seluruh bank syariah yang terdaftar di OJK sebagai populasi penelitian.

4. Penelitian selanjutnya dapat mempertimbangkan beberapa variabel independen seperti tingkat suku bunga deposito, dana pihak ketiga (DPK), inflasi, dan vatiabel lainnya yang mungkin dapat mempengaruhi tingkat bagi hasil deposito mudharabah di Indonesia.

\section{Keterbatasan Penelitian dan Pengembangan Penelitian Selanjutnya}

Penelitian ini memiliki keterbatasan dan kelemahan yang harus disempurnakan dan perlu menjadi bahan revisi pada penelitian selanjutnya. Keterbatasan tersebut antara lain:

1. Penggunaan variabel dalam penelitian ini dibatasi pada lima (5) variabel yang mempengaruhi Tingkat Bagi Hasil Deposito Mudharabah yaitu Return On Asset (ROA), Financing to Deposit Ratio (FDR), Capital Adequacy Ratio (CAR), Biaya Operasional terhadap Pendapatan Operasional (BOPO), dan Non Performing Financing (NPF) sehingga hasil penelitian yang diperoleh belum bisa memberikan kesimpulan yang bersifat umum.

2. Periode yang digunakan dalam penelitian terlalu pendek yaitu 2012-2018, sehingga pengaruh dari masing-masing variabel belum dapat diketahui dalam jangka yang lebih panjang. 


\section{DAFTAR PUSTAKA}

Ajija, Shochrul Rohmatul, dkk. 2011. Cara Cerdas Menguasai Eviews. Jakarta: Salemba Empat.

Ali, Haedar. 2018. Analisis Hubungan antara Pendapatan, Dana Pihak Ketiga, dan ROA dengan Tingkat Bagi Hasil Deposito Mudharabah. Journal of Finance and Islamic Banking. Vol. 1 No. 1 Januari-Juni 2018. P-ISSN: 2615-2967 E-ISSN: 2615-2967.

Arikunto, Suharsimi. 2016. Prosedur Penelitian Suatu Pendekatan Praktik. Jakarta: Rineka Cipta.

As, Mahmoeddin. 2010. Melacak Kredit Bermasalah. Cetakan Pertama. Jakarta: Pustaka Sinar Harapan.

Ascarya. 2014. Akad dan Produk Bank Syariah, cetakan Ke-3. Jakarta: PT. Raja Grafindo Persada.

Brigham, E. F., \& Hosuton. J. 2014. Dasar-dasar Manajemen Keuangan. Edisi 11. Jakarta: Salemba Empat.

Bungin, Burhan. 2011. Penelitian Kualitatif. Jakarta: Kencana Predana Media Group.

Cahyani, Wulandari Nur, dkk. 2017. Analisis Pengaruh ROA, ROE, BOPO, dan Suku Bunga Terhadap Tingkat Bagi Hasil Deposito Mudharabah Pada Perbankan Syariah. Jurnal MALIA. Vol. 1, 2017.

Dendawijaya, Lukman. 2012. Manajemen Perbankan. Jakarta: Ghalia Indonesia.

Fahmi, Irham. 2013. Analisis Laporan Keuangan. Bandung: Alfabeta.

Fahmi, Irfan. 2015. Manajemen Perbankan Konvensional dan Syariah. Jakarta: Mitra Wacana Media.

Farianto, Agus. 2014. Analisis Pengaruh ROA, BOPO dan Bi-Rate Terhadap Tingkat Bagi Hasil Deposito Mudharabah Pada Bank Umum Syariah di Indonesia. Jurnal Equilibrium. Volume 2, No. 1 Juni 2014.

Fatwa DSN No. 03/DSN-MUI/IV/2000 tentang deposito. Di unduh pada tanggal 7 September 2017. https://tafsirq.com/fatwa/dsn-mui/deposito.

Faza, Zulfikar \& Ummiy Fauziyah Laily. 2018. Pengaruh ROA, ROE, dan FDR terhadap Tingkat Bagi Hasil Deposito Mudharabah. Jurnal eL- Qist. Vol. 08, No. 01, April 2018. ISSN 2252-7907. 
Ghozali, Imam. 2013. Aplikasi Analisis Multivariate dengan Program SPSS. Edisi Ketujuh. Semarang: Universitas Diponegoro.

Gujarati, D.N. 2012. Dasar-dasar Ekonometrika. Terjemahan Mangunsong. R.C. Buku 2. Edisi 5. Jakarta: Salemba Empat.

Gundari. 2015. Pengaruh Kinerja Keuangan terhadap Tingkat Bagi Hasil Deposito Mudharabah pada Bank Mega Syariah Indonesia. Jurnal Profita: Kajian Ilmu Akuntansi (Profita). Vol. 3, No. 6.

Halim, Abdul. 2009. Akuntansi Sektor Publik Akuntansi Keuangan Daerah. Edisi 4. Yogyakarta: UPP STIM YKPN..

Harahap, Sofyan. 2010. Analisis Kritis atas Laporan Keuangan. Jakarta: Rajawali Pers.

Harfiah, Laila Mugi, dkk. 2016. The Impact Of ROA, BOPO, and FDR To Indonesian Islamic Bank's Mudharabah Deposit Profit Sharing. Jurnal Etikonomi Vol. 15, No. 1.

Ikatan Bankir Indonesia. 2016. Manajemen Kesehatan Bank Berbasis Risiko. Jakarta: Gramedia Pustaka Utama.

Indrajati, Ridhatullah dan Septyana Prasetyaningrum. 2014. Analisis ROE, ROA, FDR, BOPO dan Suku Bunga Terhadap Tingkat Deposito Mudharabah. Jurnal FuturE.

Indriantoro, Nur dan Supomo. 2014. Metodologi Penelitian Bisnis untuk Akuntansi dan Manajemen. Yogyakarta: BPFE.

Ismail. 2011. Perbankan Syariah. Jakarta: Kencana.

Isna K, Andryani dan Kunti Sunaryo. 2012. Analisis Pengaruh Return on asset, BOPO dan Suku Bunga Terhadap Bagi Hasil Deposito Mudharabah pada Bank Umum Syariah. Jurnal Ekonomi dan Bisnis. Vol. 11 No. 1. September 2012. pp. 29-42.

Karim, Adiwarman A. 2011. Bank Islam Analisis Fiqih dan Keuangan. Edisi 4. Jakarta: PT. Rajawali Pers.

Kasmir. 2014. Dasar-dasar Perbankan. Jakarta: Rajawali Pers.

Mudrajad, Kuncoro dan Suhardjono. 2011. Manajemen Perbankan Teori dan Aplikasi. Yogyakarta: BPFE.

Mudrajad, Kuncoro. 2013. Metode Riset untuk Bisnis dan Ekonomi. Edisi 4. Jakarta: Erlangga.

Muhammad. 2015. Manajemen Dana Bank Syariah. Ed. 1, cet.2. Jakarta: Rajawali Pers. Munawir. 2012. Analisis Informasi Keuangan. Yogyakarta: PT Liberty. 
Nofianti, Nana, Tenny Badina dan Aditiya Erlangga. 2015. Analisis Pengaruh ROA, BOPO, Suku Bunga, FDR dan NPF Terhadap Tingkat Bagi Hasil Deposito Mudharabah. Jurnal Bisnis dan Manajemen. Vol. 5, No. 1, April 2015.

Novianto, A.S. dan Hadiwidjojo, D. 2013. Analisis Faktor-faktor yang Mempengaruhi Penghimpunan Deposito Mudharabah Perbankan Syariah di Indonesia. Jurnal Implikasi Manajemen. Volume 11. Nomor 4. Desember. h.595-604.

Nur, Moh. Iskandar, M. Nasir. 2014. Pengaruh Kinerja Keuangan Terhadap Tingkat Bagi Hasil Deposito Mudharabah dan Tingkat Pengembalian Ekuitas Pada Bank Umum Syariah Di Indonesia. Diponegoro Journal Of Accounting. Volume 3, Nomor 4, Tahun 2014, Halaman 1-13.

Ongore, Vincent Okoth and Gemechu Berhanu Kusa. 2013. Determinations of Financial Performance of Commercial Banks In Kenya. International Journal of Economics and Financial Issues. Vol 3 (01): 237-252.

Rachmawaty dan Tiffany Andari Yudiana. 2015. Pengaruh ROA dan FDR Terhadap Tingkat Bagi Hasil Deposito Mudharabah. Jurnal Dinamika Akuntansi dan Bisnis. Vol. 2, No. 1 Maret 2015 YKPN : 305.

Rahayu, Putri Ayu dan Bustamam. 2016. Pengaruh Return On Asset,Bopo Dan suku Bunga Terhadap Tingkat Bagi Hasil Deposito Mudharabah Bank Umum Syariah. Jurnal Ilmiah Mahasiswa Ekonomi Akuntansi (JIMEKA). Vol. 1, No. 1, (2016) Halaman 143-149.

Rahayu, Siti. 2015. Pengaruh ROA, BOPO, Suku Bunga dan CAR terhadap tingkat Bagi Hasil Deposito Mudharabah. Jurnal Ilmiah Mahasiswa S1 Akuntansi Universitas Pandanaran. ISSN : 2502-7697, Vol. 1, No. 1.

Riyadi, Slamet. 2013. Banking Asset and Liability Management. Jakarta: Lembaga penerbitan Fakultas Ekonomi Universitas Indonesia.

Riza, Kautsar Salman. 2012. Akuntansi Perbankan Syariah. Padang: Akademia Permata.

Sabtatianto, Reandy \& Muhammad Yusuf (2018). Pengaruh BOPO, CAR, FDR, dan ROA Terhadap Tingkat Bagi Hasil Deposito Mudharabah Pada Bank Umum Syariah Di Indonesia. Jurnal Ultima Accounting. ISSN 2085-4595 Vol. 10 No. 2 Desember 2018. 
Salman, K. R. 2012. Akuntansi Perbankan Syariah Berbasis PSAK Syariah. Padang: Akademia Permata.

Santoso, Singgih. 2012. Panduan Lengkap SPSS Versi 20. Jakarta: PT Elex Media Komputindo.

Sanusi, Anwar. 2011. Metode Penelitian Bisnis. Jakarta: Salemba Empat.

Silalahi, Ulber. 2014. Metode Penelitian Sosial. Bandung: Refika Aditama.

Siswanti. 2013. Analisis Penyaluran Dana Bank Syariah. Jurnal Dinamika Manajemen. Volume 4, No: 1; 82-92. ISSN 2086-0668 (cetak); ISSN 2337-5434 (Online).

Sudarsono, Hari. 2012. Bank Lembaga Keuangan Syariah: Deskripsi dan Ilustrasi. Yogyakarta: Ekonisia.

Sudana, I Made. 2011. Manajemen Keuangan Perusahaan. Jakarta: Erlangga.

Umiyati dan Shella Munthaya Syarif. 2016. Kinerja Keuangan dan Tingkat Bagi Hasil Deposito Mudharabah Pada Bank Umum Syariah Di Indonesia. Jakarta: UIN Syarif Hidayatullah. Jurnal Akuntansi dan Keuangan Islam. Vol. 4, No. 1 (2016).

Undang-Undang Perbankan No. 7 tahun 1992 tentang Perbankan. Di unduh tanggal 7 September 2017. https://www.ojk.go.id/id/kanal/perbankan/regulasi/undangundang/Pages/undang-undang-nomor-7-tahun-1992-tentang-perbankansebagaimana-diubah-dengan-undang-undang-nomor-10-tahun-1998.aspx

Undang-Undang No. 10 Tahun 1998 tentang perubahan atas Undang-Undang No. 7 tahun 1992 tentang perbankan. Di unduh pada tanggal 7 September 2017. http://www.bi.go.id/web/id/tentang+Bi/Undangundang+BI/tentangUUNO.10Tahun1998.

Undang-Undang Republik Indonesia No. 21 Tahun 2008 tentang Perbankan Syariah. Di $\begin{array}{lllll}\text { unduh } & \text { pada } & \text { tanggal } & 7 & \text { september }\end{array}$ http://www.bi.go.id/web/id/tentang+Bi/Undangundang+BI/tentangUUNO.21Tahun2008.

Winarno, Wing Wahyu. 2009. Analisis Ekonometrika dan Statistika dengan Eviews. Edisi Kedua. Yogyakarta: UPP STIM YKPN.

Wiyono dan Maulamin. 2012. Memahami Akuntasi Syariah di Indonesia. Jakarta: Mitra Wacana Media

Wolk, H., \& Rozycki, J. D. 2013. Accounting Theory: Conceptual Issuesin in a Political and Economic Environment. Calivornia: Sage Publications. 
Yaya, Rizal et al. 2014. Akuntansi Perbankan Syariah: Teori dan Praktik Kontemporer, Edisi 2. Jakarta: Salemba Empat.

Yudiana. 2015. Analisis Perbandigan Kinerja Keuangan Bank Konvensional dan Bank Syariah. JEAM. Vol XIV April 2015.

Website: www.ojk,go.id di akses Mei 2018.

http://junaidichaniago.wordpress.com 